\title{
SUN GLASS LENSES MADE OF GROUND AND POLISHED PLATE GLASS THEREAFTER THERMALLY CURVED
}

\section{COMMERCIAL STANDARD CS159-49}

Effective Date for New Production From May 1, 1949

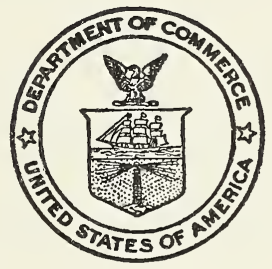

A RECORDED VOLUNTARY STANDARD

OF THE TRADE

UNITED STATES DEPARTMENT OF COMMERCE

CHARLES SAWYER, Secretary 


\section{COMMODITY STANDARDS}

Simplified Practice Recommendations and Commercial Standards are developed by manufacturers, distributors, and users in cooperation with the Commodity Standards Division of the National Bureau of Standards. The purpose of Simplified Practice Recommendations is to eliminate avoidable waste through the establishment of standards of practice for stock sizes and varieties of specific commodities that currently are in general production and demand. The purpose of Commercial Standards is to establish standard methods of test, rating, certification, and labeling of commodities, and to provide uniform bases for fair competition.

The adoption and use of a Simplified Practice Recommendation or Commercial Standard is voluntary. However, when reference to a Commercial Standard is made in contracts, labels, invoices, or advertising literature, the provisions of the standard are enforceable through usual legal channels as a part of the sales contract.

A Simplified Practice Recommendation or Commercial Standard originates with the proponent industry. The sponsors may be manufacturers, distributors, or users of the specific product. One of these three elements of industry submits to the Commodity Standards Division the necessary data to be used as the basis for developing a standard of practice. The Division, by means of assembled conferences or letter referenda, or both, assists the sponsor group in arriving at a tentative standard of practice and thereafter refers it to the other elements of the same industry for approval or for constructive criticism that will be helpful in making any necessary adjustments. The regular procedure of the Division assures continuous servicing of each effective Simplified Practice Recommendation and Commercial Standard, through review and revision, whenever, in the opinion of the industry, changing conditions warrant such action. Simplified Practice Recommendations and Commercial Standards are printed and made available by the Department of Commerce through the Government Printing Office.

\section{COMMERCIAL STANDARD FOR SUN GLASS LENSES MADE OF GROUND AND POLISHED PLATE GLASS THEREAFTER THERMALLY CURVED}

On March 1, 1949, at the instance of proponent manufacturers, a Recommended Commercial Standard for Sun Glass Lenses Made of Ground and Polished Plate Glass Thereafter Thermally Curved, adjusted in accordance with comment from interested organizations, was circulated to the trade for written acceptance. Those concerned have since accepted and approved the standard as shown herein.

Project Manager: F. W. Reynolds, Commodity Standards Division, National Bureau of Standards.

Technical Advisers: Dr. I. C. Gardner, DR. F. E. WASher, Electricity and Optics Division, National Bureau of Standards. 
for

\section{SUN GLASS LENSES MADE OF GROUND AND POLISHED PLATE GLASS THEREAFTER THER- MALLY CURVED}

\section{PURPOSE}

1. The purpose of this commercial standard is to provide a nationally recognized specification for sun glass lenses which are processed from selected ground and polished plate glass, thereafter thermally curved, to serve as an assurance and protection to purchasers, to promote fair competition between manufacturers, and to serve as a basis for certification of quality.

\section{SCOPE}

2. This commercial standard covers the focal and prismatic power, as well as freedom from defects that impair the optical functioning of these sun glass lenses. The lenses covered by this commercial standard are eye-protective (not eye-corrective) devices. They are not a substitute for prescription lenses but may be worn therewith.

\section{TYPE}

3. This specification covers sun glass lenses made entirely from ground and polished plate glass, thereafter thermally curved.

\section{GENERAL REQUIREMENTS}

4. The lenses shall be made from glass of a quality suitable for optical products, that is, glass free from strain, bubbles, seeds, or other defects visible to the unaided eye. Both optical surfaces of the flat glass before curving shall be ground and polished and free from surface defects, such as scratches, waves, and grayness, visible to the unaided eye before the process of curving. After curving the lenses shall be free of all visible defects, such as waves, striae, bubbles, and seeds, when examined by transmitted light.

5 . Surfaces of lenses shall be essentially parallel; prismatic effect shall not exceed $1 / 8$ prism diopter.

6 . Lenses shall be essentially without focal power. There shall be not more than $1 / 16$ diopter of power in any meridian and the difference in power between any two meridians shall not exceed $1 / 16$ diopter.

7. The lenses shall permit good definition and clear vision in accordance with the test of paragraph $9 \mathrm{~d}$.

8. The lenses shall have a luminous transmittance of not more than 67 percent for standard ICI source A (representative of incandescent lamp light). 


\section{OPTICAL TESTS FOR LENSES}

9a. The lenses shall be tested, as worn, for prismatic power, refractive power, and definition by any standard methods of sufficient accuracy for the purpose, and which are equivalent to the National Bureau of Standards methods listed below.

9b. Prismatic power.-The lenses are to be tested for prismatic power with a 12-power telescope which has an effective aperture not less than $3 / 4$ inch and is equipped with cross-hairs in the focal plane of the ocular. The telescope is to be focused on an illuminated target placed at a distance of 35 feet from the telescope objective, comprising a control dot and a concentric circle 1.0 inch in diameter. The telescope is to be so aligned that the image of the central dot falls on the intersection of the cross-hairs in the focal plane of the ocular. The lens is to be held as worn in front of the objective lens of the telescope, and if the intersection point of the cross-hairs falls without the image of the circle the prismatic power of the lens exceeds $1 / 8$ prism diopter.

9c. Refractive power.-The lenses are to be tested, as worn, for refractive power by any suitable instrument, such as a lensometer, vertometer, or telescope. The telescope method of measuring refractive power requires an external focusing telescope with effective aperture not less than $3 / 4$ inch and with magnifying power not less than 12. The telescope is focused on an illuminated test chart (described in National Bureau of Standards Circular C428, obtainable from the Superintendent of Documents, Government Printing Office, Washington 25, D. C., at 50 cents a copy) placed at a distance of 35 feet from the telescope objective. The telescope is calibrated by successively placing standard lenses of powers $+1 / 16$ and $-1 / 16$ diopters in front of the objective and locating the positions of best focus. These positions are marked by scratches on the draw tubes or other suitable index marks. The lens is to be held in front of the calibrated telescope, and if the position of the best focus falls outside the index marks the refractive power is in excess of $\pm 1 / 16$ diopter. If the separation of the best focus positions for vertical and horizontal lines in the pattern exceeds $1 / 2$ the separation of the index marks, the difference in refractive power for two meridians exceeds $1 / 16$ diopter.

9d. Definition test.-The lenses are to be tested for definition with a 12-power telescope which has an effective aperture of $3 / 4$ inch and is focused at a distance of 35 feet on an illuminated test chart. As a test chart the resolving power chart pattern 20 of National Bureau of Standards Circular C428 may be used. An advantage in adopting this chart is that by its use it becomes possible to provide all inspectors with identical charts, whereas if charts are improvised at different places they are likely to be different. The pattern marked 20 should be clearly resolved with the target placed at a distance of 35 feet from the telescope objective used for testing lenses.

Nоте.-Chart pattern 20, when resolved under the above conditions, indicates a resolving power of 24 seconds, and since the resolving power of the normal eye is approximately 60 seconds the test is not unduly stringent. 
10. Luminous-transmittance test for lenses.-The luminous transmittance of the lens for standard source A shall be determined by illuminating the lens by a gas-filled, tungsten-filament lamp of from 50 to 200 watts operated at its rated voltage, and by measuring the transmitted flux relative to the incident flux either photometrically by an observer having a luminosity function within normal limits or by a physical photometer adjusted by means of a filter to agree closely with the standard luminosity function recommended by the International Commission on Illumination.

\section{IDENTIFICATION}

11a. In order that purchasers may be assured that sun glass lenses purchased actually comply with all requirements of the Commercial Standard, it is recommended that manufacturers include the following statement in conjunction with their name and address on labels, invoices, sales literature, etc.:

These sun glass lenses made from ground and polished plate glass thereafter thermally curved, comply with Commercial Standard CS159-49, developed by the trade under the procedure of the National Bureau of Standards, and issued by the U. S. Department of Commerce.

11b. When available space on labels is insufficient for the full statement in legible type, an abbreviated statement, as follows, is recommended:

Complies with CS159-49, as developed by the trade, and issued by the U. S. Department of Commerce.

\section{EFFECTIVE DATE}

12. Having been passed through the regular procedure of the Commodity Standards Division, and approved by the acceptors hereinafter listed, this commercial standard was issued by the United States Department of Commerce, effective from May 1, 1949.

\section{EDWIN W. ELY,}

Chief, Commodity Standards Division.

\section{HISTORY OF PROJECT}

13. On January 27, 1948, a group of interested manufacturers requested the cooperation of the National Bureau of Standards in the establishment of a commercial standard for sun glass lenses made from curved plate glass, and submitted a proposed specification to be used as a basis for the establishment of the commercial standard.

14. This specification was submitted to a number of manufacturers, distributors, users, and other interested organizations, for comment, on February 10, 1948. After adjustment in agreement with the consensus of comment received, a recommended commercial standard was circulated to the trade for written acceptance on March 1, 1949.

15. Acceptances in writing, estimated to represent a satisfactory majority, having been received, an announcement was issued on March 
31,1949 , that the standard would become effective for new production on May 1, 1949.

\section{STANDING COMMITTEE}

16. The following individuals comprise the membership of the standing committee, which is to review, prior to circulation for acceptance, revisions proposed to keep the standard abreast of progress. Comment concerning the standard and suggestions for revision may be addressed to any member of the committee or to the Commodity Standards Division, National Bureau of Standards, which acts as secretary for the committee.

Daniel DeGorter (Chairman), Plate Glass Sales Agency, 130 West 31st Street, New York 1, N. Y.

Blanke, T. L., 100 West 31st Street, New York 1, N. Y. (Representing National Retail Dry Goods Association.)

Brackett, Dr. Frederick S., National Institute of Health, Bethesda 14, Md.

Corwin, Max, Regal Glass Corporation, 421 East 13th Street, New York 3, N. Y.

Dargavel, J. W., 205 West Wacker Drive, Chicago 6, Ill. (Representing the National Association of Retail Druggists.)

Enged, Henry H., Modern Glass Processing Corporation, 1541 Schaeffer Street, Brooklyn 27, N.'Y.

Fletcher, Leslie S., 44 Trinity Place, New York 6, N. Y. (Representing American Standards Testing Bureau, Inc.)

Frates, George, National Press Building, Washington, D. C. (Alternate, representing the National Association of Retail Druggists.)

Hoskins, H. W., 1148 Main Street, Bridgeport 1, Conn. (Representing State of Connecticut Commission of Opticians, and Guild of Prescription Opticians of America, Inc.)

Imus, Dr. Henry A., Office of Naval Research, Navy Department, Washington 25, D. C.

LAMPERT, Chester, Irving Lampert Co., Inc., 236 Liberty Avenue, Brooklyn 7, N. Y.

Volk, Irving J., New York Eye Protection Company, Inc., 60 Broadway, Brooklyn $11, \mathrm{~N}$. Y.

Washer, Dr. Francis E., National Bureau of Standards, Washington 25, D. C. 


\section{ACCEPTANCE OF COMMERCIAL STANDARD}

If acceptance has not previously been filed, this sheet properly filled in, signed, and returned will provide for the recording of your organization as an acceptor of this commercial standard.

Commodity Standards Division,

Date.

National Bureau of Standards,

Washington 25, D. C.

Gentlemen:

We believe that the Commercial Standard CS159-49 constitutes a useful standard of practice, and we individually plan to utilize it as far as practicable in the

production $^{1} \quad$ distribution $^{1} \quad$ purchase $^{1}$ testing ${ }^{1}$

ब of sun glass lenses made from ground and polished plate glass, thereafter thermally curved. We reserve the right to depart from it as we deem advisable.

We understand, of course, that only those articles which actually comply with the standard in all respects can be identified or labeled as conforming thereto.

Signature of authorized officer

(in ink)

(Kindly typewrite or print the following lines)

Name and title of above officer

Organization

Street address

City, Zone, and State

1 Underscore which one. Please see that separate acceptances are filed for all subsidiary companies and affiliates which should be listed separately as acceptors. In the case of related interests, trade associations, trade papers, etc., desiring to record their general support, the words "General Support" should be added after the signature. 


\section{TO THE ACCEPTOR}

The following statements answer the usual questions arising in connection with the acceptance and its significance:

1. Enforcement.-Commercial standards are commodity specifications voluntarily established by mutual consent of those concerned. They present a common basis of understanding between the producer, distributor, and consumer and should not be confused with any plan of governmental regulation or control. The United States Department of Commerce has no regulatory power in the enforcement of their provisions, but since they represent the will of the interested groups as a whole, their provisions through usage soon become established as trade customs, and are made effective through incorporation into sales contracts by means of labels, invoices, and the like.

2. The acceptor's responsibility. - The purpose of commercial standards is to establish for specific commodities, nationally recognized grades or consumer criteria and the benefits therefrom will be measurable in direct proportion to their general recognition and actual use. Instances will occur when it may be necessary to deviate from the standard and the signing of an acceptance does not preclude such departures; however, such signature indicates an intention to follow the commercial standard where practicable, in the production, distribution, or consumption of the article in question.

3. The Department's responsibility.-The major function performed by the Department of Commerce in the voluntary establishment of commercial standards on a Nation-wide basis is fourfold; first, to act as an unbiased coordinator to bring all interested parties together for the mutually satisfactory adjustment of trade standards; second, to supply such assistance and advice as past experience with similar programs may suggest; third, to canvass and record the extent of acceptances and adherence to the standard on the part of producers, distributors, and users, and fourth, after acceptance, to publish and promulgate the standard for the information and guidance of buyers and sellers of the commodity.

4. Announcement and promulgation.-When the standard has been endorsed by a satisfactory majority of production or consumption in the absence of active valid opposition, the success of the project is announced. If, however, in the opinion of the Standing Committee or the Department of Commerce, the support of any standard is inadequate, the right is reserved to withhold promulgation and publication. 


\section{ACCEPTORS}

17. The organizations listed below have individually accepted this standard for use as far as practicable in the production, distribution, testing, or purchase of sun glass lenses made of ground and polished plate glass, thereafter thermally curved. In accepting the standard, they reserved the right to depart therefrom as they individually deem advisable. It is expected that articles which actually comply with the requirements of this standard in all respects will be regularly identified or labeled as conforming thereto, and that purchasers will require such specific evidence of conformity.

\section{ASSOCIATIONS \\ (General Support)}

National Retail Dry Goods Association, New York, N. Y.

\section{FIRMS AND OTHER INTERESTS}

Abraham \& Straus, Inc., Brooklyn, N. Y. Apex Specialties Co., New Rochelle, N. Y. Ark-Wise Optical Co., Brooklyn, N. Y.

Athol Comb Co., New York, N. Y.

B \& M Distributing Co., Inc., Cranston, R. I.

Bauer, Henry H., Inc., New Y̌ ork, N. Y.

Benson, N. P., Optical Co., Minneapolis, Minn.

Buhl Optical Čo., Pittsburgh, Pa.

Bullard, E. D., Co., San Francisco, Calif.

Central of Georgia Railway Co., Savannah, Ga.

City Opticians, Greensboro, N.C.

Clinton Optical Co., Inc., Rochester, N. Y.

Comptone Co., Ltd., New York, N. Y.

Du Paul-Central Optical Co., Inc., Southbridge, Mass.

Eye-Site Laboratories, Division of Sundial Optical Co., Olneyville, R.I.

Franklin Glass Corp., Butler, $\mathrm{Pa}$

Gem Optical Manufacturing Co., Brooklyn, N. Y. Global Optical Co., New York, N. Y.

Goerz, C. P., American Optical Co., New York, N.Y. (General support.)

Goldgram Bros., New York, N. Y.

Johnston Optical Co., Detroit, Mich:

Karol Optical Co., Inc., NEW York, N. Y.

Lampert, Irving, Co., Inc., Brooklyn, N. Y.
Lavoie, Wilfred H., Southbridge, Mass.

Marsco Manufacturing Co., Chicago, Ill.

May Manufacturing Corp., New York, N. Y.

Mayer, Geo., \& Co., Philadelphia, $\mathrm{Pa}$

McIntire, Magee \& Brown Co., Philadelphia, $\mathrm{Pa}$

Merlin Manufacturing Co., New York, N. Y'

Meyrowitz, E. B., Inc., New York, N. Y.

Modern Glass Processing Corp., Brooklyn, N. Y.

Mojay Products, Inc., Providence, R. I.

New York Eye Protection Co., Inc., Brooklyn, N. Y.

Pathway Plastic Corp., New York, N. Y.

Philray Products Corp., New York, N. Y.

Plate Glass Sales Agency, New York, N. Y.

Quinton-Duffens Optical Co., Topeka, Kans.

Raynard Optical Co., Brooklyn, N.Y

Regal Glass Corp., New York, N. Y .

Ridgway's, Evansville, Ind.

Ryan Aeronautical Co., San Diego, Calif.

Safety First Supply Co., Pittsburgh, Pa.

Sills \& Greene Optical Corp., Brooklyn, N. Y . Simon, Ray, Optical Co., Chicago, nl.

Snell, Foster D., Inc., New York, N. Y.

Sundial Optical Co., New York, N. Y.

Sunware Products, Inc., New York, N. Y.

Universal Sunglass Co., Inc., New York, N. Y.

Vorwerk Optical Co., Äkron, Ohio.

Winters Optical Manufacturing Ċo., New York, N. Y.

Zenith Optical Laboratory, New York, N. Y.

\section{UNITED STATES GOVERNMENT}

Air Matériel Command, United States Air Force, Dayton, Ohio. 


\section{COMMERCIAL STANDARDS}

CS No.

Item

0-40. Commercial standards and their value to business (third edition).

1-42. Clinical thermometers (third edition)

2-30. Mopsticks.

3-40. Stoddard solvent (third edition).

4-29. Staple porcelain (all-clay) plumbing fixtures.

5-46. Pipe nipples; brass, copper, steel and wrought-iron (second edition).

6-31. Wrought-iron pipe nipples (second edition). Superseded by CS5-46.

7-29. Standard weight malleable iron or steel screwed unions.

8-41. Gage blanks (third edition).

9-33. Builders' template hardware (second edition)

10-29. Brass pipe nipples. Superseded by CS5-46.

11-41. Moisture regains of cotton yarns (second edition)

12-48. Fuel oils (sixth edition).

13-44. Dress patterns (fourth edition).

14-43. Boys' button-on waists, shirts, junior and sport shirts (made from woven fabrics) (third edition).

15-46. Men's pajama sizes (made from woven fabrics) (third edition)

16-29. Wallpaper.

17-47. Diamond core drill fittings (fourth edition)

18-29. Hickory golf shafts.

19-32. Foundry patterns of wood (second edition)

20-47. Staple vitreous china plumbing fixtures (fourth edition).

21-39. Interchangeable ground-glass joints, stopcocks, and stoppers (fourth edition).

22-40. Builders' hardware (nontemplate) (second edition).

23-30. Feldspar.

24-43. Serew threads and tap-drill sizes.

25-30. Special screw threads. Superseded by CS24-43.

26-30. Aromatic red cedar closet lining.

27-36. Mirrors (second edition).

28-46. Cotton fabric tents, tarpaulins and covers (second edition).

29-31. Staple seats for water-closet bowls.

$30-31$. Colors for sanitary ware. (Withdrawn as commercial standard, March 15, 1948).

31-38. Wood shingles (fourth edition).

32-31. Cotton cloth for rubber and pyroxylin coating.

33-43. Knit underwear (exclusive of rayon) (second edition).

34-31. Bag, case, and strap leather.

35-47. Hardwood plywood (third edition).

36-33. Fourdrinier wire cloth (second edition).

37-31. Steel bone plates and screws.

38-32. Hospital rubber sheeting.

39-37. Wool and part wool blankets (second edition) (Withdrawn as commercial standard, July 14, 1941).

40-32. Surgeons' rubber gloves.

41-32. Surgeons' latex gloves.

42-43. Structural fiber insulating board (third edition).

43-32. Grading of sulphonated oils.

44-32. Apple wraps.

45-48. Douglas fir plywood (eighth edition).

46-40. Hosiery lengths and sizes (third edition).

47-34. Marking of gold-filled and rolled-gold-plate articles other than watch cases.

48-40. Domestic burners for Pennsylvania anthracite (underfeed type) (second edition).

49-34. Chip board, laminated chip board, and miscellaneous boards for bookbinding purposes.

50-34. Binders board for bookbinding and other purposes.

51-35. Marking articles made of silver in combination with gold.

52-35. Mohair pile fabrics (100-percent mohair plain velvet, 100 -percent mohair plain frieze, and 50-percent mohair plain frieze).

53-35. Colors and finishes for cast stone.

54-35. Mattresses for hospitals.

55-35. Mattresses for institutions.
CS No.

Item

56-49. Oak flooring (third edition).

57-40. Book cloths, buckrams, and impregnated fabrics for bookbinding purposes except library bindings (second edition).

58-36. Woven elastic fabrics for use in overalls (overall elastic webbing).

59-44. Textiles-testing and reporting (fourth edition).

60-48. Hardwood dimension lumber (second edition).

61-37. Wood-slat venetian blinds.

62-38. Colors for kitchen accessories.

63-38. Colors for bathroom accessories.

64-37. Walnut veneers.

65-43. Methods of analysis and of reporting fiber composition of textile products (second edition).

66-38. Marking of articles made wholly or in part of platinum.

67-38. Marking articles made of karat gold.

68-38. Liquid hypochlorite disinfectant, deodorant, and germicide.

69-38. Pine oil disinfectant.

70-41. Phenolic disinfectant (emulsifying type) (second edition) (published with CS71-41)

71-41. Phenolic disinfectant (soluble type) (second edition) (published with CS70-41).

72-38. Household insecticide (liquid spray type).

73-48. Old growth Douglas fir, Sitka spruce and Western hemlock standard stock doors (fourth edition).

74-39. Solid hardwood wall paneling.

75-42. Automatic mechanical draft oil burners designed for domestic installations (second edition).

76-39. Hardwood interior trim and molding.

77-48. Enameled cast iron plumbing fixtures (second edition)

78-40. Ground-and-polished lenses for sun glasses (second edition) (published with CS79-40).

79-40. Blown, drawn, and dropped lenses for sun glasses (second edition) (published with CS78-40).

80-41. Electric direction signal systems other than semaphore type for commercial and other vehicles subject to special motor vehicle laws (after market).

81-41. Adverse-weather lamps for vehicles (after market).

82-41. Inner-controlled spotlamps for vehicles (after market).

83-41. Clearance, marker, and identification lamps for vehicles (after market).

84-41. Electric tail lamps for vehicles (after market).

85-41. Electric license-plate lamps for vehicles (after market).

86-41. Electric stop lamps for vehicles (after market).

87-41. Red electric warning lanterns.

88-41. Liquid burning flares.

89-40. Hardwood stair treads and risers.

90- . (Reserved for power shovels and cranes.)

91-41. Factory-fitted Douglas fir entrance doors.

92-41. Cedar, cypress, and redwood tank stock lumber.

93-41. Portable electric drills (exclusive of high frequency).

94-41. Calking lead.

95-41. Iread pipe.

96-41. Lead traps and bends.

97-42. Electric supplementary driving and passing lamps for vehicles (after market).

98-42. Artists' oil paints.

99-42. Gas floor furnaces-gravity circulating type

100-47. Porcelain-enameled steel utensils (third edition).

101-43. Flue-connected oil-burning space heaters equipped with vaporizing pot-type burners.

102- . (Reserved for Diesel and fuel-oil engines.)

103-48. Rayon jacquard velour (with or without other decorative yarn) (second edition).

104-46. Warm-air furnaces equipped with vaporizing pot-type oil burners (second edition). 
CS No.

Item

105-48. Mineral wool insulation for low temperatures (second edition).

106-44. Boys' pajama sizes (woven fabrics) (second edition).

107-45. Commercial electric-refrigeration condensing units (second edition). (Withdrawn as commercial standard September 4, 1947.) 108-43. Treading automobile and truck tires.

109-44. Solid-fuel-burning forced-air furnaces.

110-43. Tire repairs-vulcanized (passenger, truck, and bus tires).

111-43. Earthenware (vitreous-glazed) plumbing fixtures.

112-43. Homogeneous fiber wallboard.

113-44. Oil-burning floor furnaces equipped with vaporizing pot-type burners.

114-43. Hospital sheeting for mattress protection.

115-44. Porcelain-enameled tanks for domestic use.

116-44. Bituminized-fibre drain and sewer pipe.

117-44. Mineral wool; blankets, blocks, insulating cement, and pipe insulation for heated industrial equipment.

118-44. Marking of jewelry and novelties of silver.

(E)119-45.1 Dial indicators (for linear measurements).

120-48. Standard stock ponderosa pine doors (third edition).

121-45. Women's slip sizes (woven fabrics).

122-45. Western hemlock plywood.

$123-45$. Grading of diamond powder.

(E) 124-45.1 Master disks.

125-47. Prefabricated homes (second edition).

126-45. Tank-mounted air compressors.

127-45. Self-contained mechanically refrigerated drinking water coolers.

128-45. Men's sport shirt sizes - woven fabrics (other than those marked with regular neckband sizes).

129-47. Materials for safety wearing apparel (second edition).

130-46. Color materials for art education in schools.

131-46. Industrial mineral wool products, all typestesting and reporting.
CS No.

Item

132-46. Hardware cloth.

133-46. Woven wire netting.

134-46. Cast aluminum cooking utensils (metal composition).

135-46. Men's shirt sizes (exclusive of work shirts)

136-46. Blankets for hospitals (wool, and wool and cotton).

137-46. Size measurements for men's and boys' shorts (woven fabrics).

138-47. Insect wire screening.

139-47. Work gloves.

140-47. Testing and rating convectors.

141-47. Sine bars, blocks, plates, and fixtures.

142-47. Automotive lifts.

143-47. Standard strength and extra strength perforated clay pipe.

144-47. Formed metal porcelain enameled sanitary ware.

145-47. Testing and rating hand-fired hot-watersupply boilers.

146-47. Gowns for hospital patients.

147-47. Colors for molded urea plastics.

148-48. Men's circular flat and rib knit rayon underwear.

149-48. Utility type house dress sizes.

150-48. Hot-rolled rail steel bars (produced from tee-section rails).

151-48. Body measurements for the sizing of apparel for infants, babies, toddlers, and children (for the knit-underwear industry).

152-48. Copper naphthenate wood-preservative.

153-48. Body measurements for the sizing of apparel for girls (for the knit-underwear industry).

154- (Reserved for wire rope).

155-49. Body measurements for the sizing of apparel for boys (for the knit-underwear industry).

156-49. Colors for polystyrene plastics.

157-49. Ponderosa pine and sugar pine plywood.

158-49. Model forms for girls' apparel.

159-49. Sun-glass lenses made of ground and polished plate glass, thereafter thermally curved.

1 Where "(E)" precedes the CS number, it indicates an emergency commercial standard, drafted under war conditions with a view toward early revision.

Nотісе.- Those interested in commercial standards with a view toward accepting them as a basis of everyday practice may secure copies of the above standards, while the supply lasts, by addressing the Commodity Standards Division, National Bureau of Standards, Washington 25, D. C. 
